\title{
The patient relationship and therapeutic techniques of the South Sotho traditional healer
}

\author{
MG Pinkoane, Registered student: M. Cur. (Community nursing) \\ Potchefstroom campus of the North-West University
}

M Greeff, D.Cur. (Psychiatric Nursing)

School of Nursing Science, Potchefstroom campus of the North-West University

MJS Williams, M. Cur. (Nursing Education)

School of Nursing Science, Potchefstroom campus of the North-West University

\section{Keywords:}

relationship, traditional healer, traditional medicine, healing process, biomedical personnel, biomedicine, and therapeutic techniques, patient

\section{Correspondence address:}

Prof M. Greeff

School of Nursing Science,

Potchefstroom campus of the North-West University

Private Bag x 6001

Potchefstroom

2520

Tel : (018) 299-1901

Fax : (018) 299-1827

E-mail : vpkmg@puk.ac.za

\section{Abstract: Curationis 28(4): 20-30}

Until 1996 the practice of traditional healers was outlawed in South Africa and not afforded a legal position in the community of health care providers. In 1978 the World Health Organization (WHO) identified traditional healers as those people forming an essential core of primary health care workers for rural people in the Third World Countries. However in 1994 the new South African government identified traditional healers as forming an essential element of primary health care workers. It is estimated that $80 \%$ of the black population uses traditional medicine because it is deeply rooted in their culture, which is linked to their religion. The traditional healer shares with the patient a world view which is completely alien to biomedical personnel. Therapeutic techniques typically used in traditional healing conflict with the therapeutic techniques used in biomedicine. The patients' perceptions of traditional healing, their needs and expectations, may be the driving force behind their continuous persistence to consult a traditional healer, even after these patients may have sought the therapeutic techniques of biomedical personnel. The operation of both systems in the same society creates a problem to both providers and recipients of health care. Confusion then arises and the consumer consequently chooses the services closer to her.

The researcher aimed at investigating the characteristics of the relationship between the traditional healers and the patients, explored the therapeutic techniques that are used in the South Sotho traditional healing process, and investigated the views of both the traditional healers and the patients about the South -Sotho traditional healing process, to facilitate incorporation of the traditional healers in the National Health Care Delivery System. A qualitative research design was followed. Participants were identified by means of a non-probable, purposive voluntary sample. Data was collected by means of a video camera and semi-structured interviews with the six traditional healers and twelve patients, as well as by taking field notes after each session. Data analysis was achieved by means of using a checklist for the video recordings, and decoding was done for the interviews. A co-coder and the researcher analysed the data independently, after which three consensus discussions took place to finalise the analysed data.

The researcher made conclusions, identified shortcomings, and made recommendations for application to nursing education, nursing research and nursing practice. The recommendations for nursing practice are reflected in the form of guidelines for the incorporation of the traditional healers in the National Health Care Delivery System. 


\section{Opsomming}

Tot en met 1996 is die praktyk van tradisionele genesers nie gewettig in Suid-Afrika nie en het dit ook nie ' $n$ wettige posisie beklee by die verskaffers van gesondheidsorg nie. In 1978 is tradisionele genesers deur die Wêreldgesondheidsorganis asie geïdentifiseer as ' $n$ belangrike bron van primêre gesondheidsorg vir landelike inwoners in Derdewêreldlande. In 1994 met die verandering van die Suid Afrikaanse regering, het die neiging om tradisionele genesers deel te maak van die kern van primêre gesondheidsorg egter posgevat. Daar word geraam dat omtrent $80 \%$ van die swart bevolking in Suid Afrika gebruik maak van tradisionele medisyne aangesien dit diep gewortel is in hul kultuur wat gebonde is aan hulle geloof. Terapeutiese tegnieke wat gebruik word vir tradisionele genesing is heeltemal in stryd met terapeutiese tegnieke in bio-medisyne. Die pasiënt se persepsie van tradisionele genesing, sy/ haar behoeftes en verwagtinge word beskou as die dryfveer vir sy/haar volgehoue besoeke aan tradisionele genesers, selfs al het hy/sy die advies van bio-mediese personeel ingewin. Die bestaan van beide praktyke in dieselfde gemeenskap skep probleme vir voorsieners sowel as die ontvangers van gesondheidsorg. Dit gee aanleiding tot verwarring en die verbruiker maak gevolglik gebruik van naaste besikikbare dienste.

Die navorsing was daarop gerig om ondersoek in te stel na die verhouding tussen die Suid-Sotho tradisionele geneser en die pasient, die terapeutiese tegnieke wat gebruik word in die proses van Suid-Sotho tradisionele genesing, asook die sienings die tradisionele genesers sowel as die pasiënt omtrent Suid-Sotho tradisionele genesing proses, om sodoende die inkorporering van die tradisionele genesers in die Nasionale Gesondheidsorgsisteem te fasiliteer. ' $n$ Kwalitatiewe navorsings-ontwerp is gevolg om deelnemers te identifiseer by wyse van 'n nie-waarskynlike, doelgerigte, vrywillige steekproef. Data insameling is gedoen by wyse van video-opnames en die voer van semigestruktureerde onderhoude met ses tradisionele genesers en twaalf pasiënte. Veldnotas is na afloop van elke sessie geneem. Data analise vir die video opnames is deur middel van " $n$ kontrole lys uitgevoer en vir die onderhoude is van oop kodering gebruik gemaak. ' $n$
Onafhanklike ködeerder en die navorser het die data afsonderlik geanaliseer en gekodeer, daarna is drie konsensusgesprekke gevoer om tot ' $n$ vergelyk te kom.

Die navorser het tot sekere gevolgtrekkings gekom, tekortkommings is geidentifiseer en aanbevelings is geformuleer vir toepassing in die verpleegonderwys, verpleegnavorsing en verpleegpraktyk. Die aanbevelings vir verpleegpraktyk word as riglyne gestel om die tradisionele geneser in te skakel as deel van die Nasionale Gesondheidsorg sisteem.

\section{Introduction and problem statement}

In South Africa traditional healers are the health care choice of a large number of the African population. It is estimated that $80 \%$ of the black population uses traditional medicine (Freeman \& Motsei, 1992a:1185; Abdool Karim, Ziqubu Page and Arendse, 1994:3). The majority of black people reside in rural areas with the result that the country consists of a combination of a Third World and a developed country. It is in these rural areas and urban "townships" that many people turn to traditional healers because they are freely accessible and sometimes the only source of health care available (Mankazana, 1979: 1005; Freeman \& Motsei, 1992a:1186). Apart from the latter two reasons, traditional healing is also deeply rooted in black people's culture. Abdool Karim et al., (1994:3) mentions that black people's cultural heritage is linked to their religion. Arthur (1997:63) also argues that this religion is a frame of reference, which forms the "fabric" of traditional African life - a fabric that closely connects all thoughts and activities of the people, where health and illness form an integral part of this religious system.

A decision to consult a traditional healer in times of ill health is the beginning of the formation of a relationship between the traditional healer and the patient. This relationship is usually very close and intense (Gumede, 1990:164), because the traditional healer as an existing resource person, is accessible, popular (Hopa, Simbayi and du Toit, 1998:8), and available to the black people. The traditional healer " is of the people and comes from among them" (Gumede, 1990:164).

Abdool Karim et al., (1994:2) declares, that the traditional healer shares with the patient a view of the world and the way in which it works, something completely alien to biomedical personnel. Not only does he provide comfort and support to both the patient and relatives, he is also a good listener (Gumede, 1990: 153), and an expert in providing comfort and reassurance (Musi, 1996:31).

Therapeutic techniques typically used in traditional healing, sometimes conflict with the therapeutic techniques used in biomedicine. Biomedical therapeutic techniques are based on a scientific approach (Arthur, 1997:63), while those of traditional healing, according to Gumede (1990:154), are unscientific, crude and unplanned and, therefore, perceived as strange in the view of biomedical personnel's understanding of healing. It is from this premise, that traditional healers' work continue to be shunned, kept secret (Freeman \& Motsei, 1992a:1188), and treated with suspicion to an undue degree (Mburu, 1977:167). Therapeutic techniques used follows different stages, starting with supernatural divination. This is a process of diagnosis to identify a patient's problems. After the identification of the cause through supernatural divination follows the removal of the hostile source or neutralization of the sorcerer (YangniAngate, 1981:24). If the hostile source is transgressing the ancestors, their forgiveness is sought by sacrifices, rituals and ceremonies or by using certain medications (Abdool Karim et al., 1994:5). Fees are charged according to each therapeutic technique used, and this schedule is neither fixed nor standardized and arrangements for postponed payment are easily made (Ngubane, 1977:103)

Parallel to the relationship of trust and therapeutic techniques used, are certain perceptions of the traditional healer and the patients about the entire healing process. These perceptions are inherent in traditional beliefs, and are identified to be the driving force behind the patients' persistence to consult the traditional healer, even after the patient may have sought the therapeutic techniques of biomedical personnel (Abdool Karim et al., 1994:5). These simultaneous consultations create a problem to both providers and recipients of health care. When complications ensue, one blames the other because of lack of communication and trust between the two health systems. Each protects its own domain by preaching the value of 
using one and not the other. This creates a dilemma to the consumer, who sees both systems as serving his/her needs. This dilemma, gives rise to confusion and as a result the consumer chooses the services closer to him/her. It is because of this dilemma, that there was a need to investigate the following aspects:

- the characteristics of the relationship between the SouthSotho traditional healer and his patients,

- the therapeutic techniques used in South -Sotho traditional healing process, and

- the views of both the South Sotho traditional healers and the patients regarding the South-Sotho traditional healing process.

This was done in order to formulate guidelines for incorporation of the South -Sotho traditional healers into the National Health Care Delivery System.

\section{Research design and method}

The research design used for this research was qualitative in nature. The context was the South- Sotho culture of the Maokeng, Ikageng and Sebokeng townships.

\section{Literature study}

A literature study was undertaken to:

- $\quad$ ground the check list and the semi-structured interview schedules. No perceptions were included;

- $\quad$ confirm the study of the SouthSotho traditional medicine, the characteristics of the relationship between the South -Sotho traditional healer and his patients as well as the therapeutic techniques used in the South - Sotho traditional healing process.

\section{Sample}

For the purpose of this research, samples were selected from two populations, namely South -Sotho traditional healers and their patients residing in the three towns of Maokeng, Ikageng and Sebokeng where the research was undertaken. These two populations were chosen purposively and voluntarily and satisfied the criteria for selection, which in the case of the traditional healers were that they should have been practicing for two or more years, of South -Sotho ethnic group and be residing in one of the three towns where the research was to be undertaken. The criteria for the patients was similar and included that they should be frequent users of traditional medicines, and be prepared to be interviewed and video taped while interacting with the traditional healer and when using the prescribed therapeutic techniques.

\section{Data collection method}

Data collection was divided into two phases. The first phase was achieved by means of making video recordings of the interaction between the six traditional healers and their patients as well as of the patients when they used the therapeutic techniques prescribed by the traditional healers. The video recordings were done by a technician, following the instructions of the researcher. Some of these recordings were done at the patients' homes, and others at the traditional healers' homes.

The second phase was conducted by the researcher using an audiotape to record the interviews of the six traditional healers and two of each of their patients (twelve patients in total). The semi structured interviews of the traditional healers consisted of the following questions:

- $\quad$ how would you describe your work as a traditional healer;

- what do you see as the traditional healing process;

- $\quad$ how do you see your relationship with the patient in the healing process;

- what is the role of the patient in the healing process;

- what is your view about being chosen by the ancestors to be a traditional healer;

$\bullet$ what therapeutic techniques do you use in traditional healing;

- how do you know when to use divination and to what extend does it guide you to choose a specific technique;

- what healing methods do you use and which do you prefer to use;

- what do you do when the patient reacts differently from what you expect; and how do you handle these different reactions?
For the patients the questions were:

- what do you see as traditional healing;

- what do you see as the work of the traditional healer in the healing process;

- what makes you to use traditional healing methods and why do you prefer to go to the traditional healer;

- $\quad$ how do you use traditional healing methods;

- $\quad$ how do you see your relationship with the traditional healer;

- $\quad$ if a medical doctor gives you medicine, does it work for you;

- do you ever encounter problems with the traditional healers' medicines; and what do you do when you encounter these problems?

Field notes were taken at the end of each of the video recording and interviewing sessions. Data saturation for the video recordings was reached after the sixth videotape was recorded; for the semistructured interviews of the traditional healers, after the sixth interview; and for the patients, after the eighth interview. However, a further four interviews were conducted to confirm the findings.

The video and audiotape cassettes were transcribed verbatim and translated into English in preparation for the data analysis which was conducted by the researcher and an independent co- coder.

\section{Data analysis}

Data analysis for this research was divided into two categories. Firstly, data analysis of the video tape recordings which was done by means of viewing and coding with a checklist (Mann, Walkup, Berryman, Palmer and Bassey, 1994:226230) depicting behaviours and events that occurred or did not occur (Dorwick, 1991:131). Secondly an analysis was made of the audiotape transcriptions which were transcribed verbatim and translated by the researcher. Open coding was done by means of a technique described by Tesch (in Cresswell, 1990:153-159). The use of double coding was employed which involved that a nurse specialist and the researcher analysed and coded the data independently, after which three 
consensus discussions took place to finalise the analysed data.

\section{Trustworthiness}

In qualitative research trustworthiness is described as a measure to ensure reliability and validity. For this research a combination of the approach of Guba (in Krefting, 1991:214) and the model of Woods and Catanzaro (1988:136-137) was used to measure reliability and validity. Table one illustrates the measures for trustworthiness.

\section{Ethical aspects}

Ethical aspects specific to this research were taken into consideration as detailed in the guidelines for the Democratic Nurses' Organisation of South Africa (1998:1-7), as well as those of the Department of Health (2000:1-75). These are as follows:

- $\quad$ The quality of the research was ensured by thorough planning, implementation and documentation of the research findings.

- $\quad$ Confidentiality and anonymity was ensured by not revealing the names of participants in the repon, except to the researcher, supervisor and co- supervisor.

- $\quad$ Privacy was ensured by putting up a "no disturbance sign" in the areas where the video and interviews were recorded.

- Written consent was obtained from both traditional healers and patients before the study was commenced in a written format, and the right to withdraw was explained.

- $\quad$ Risks were minimised by proper planning and implementation of the research process.

- $\quad$ The research would be termination if relevant data could not be obtained.

\section{Discussion of the results}

\section{and literature control}

The results and discussion of this research falls into two sections. The first section depicts the results and discussion of the video taped interaction between the six traditional healers and their twelve patients, and the use of therapeutic techniques. The second section, which was obtained by the use of semi-structured interviews, depicts the different views of the six traditional healers and their twelve patients about the traditional healing process. The discussion in this section is illustrated with quotations derived from the interviews with the traditional healers and their patients. The findings are confirmed by a literature control.

\section{Results of the video recordings}

The results of the video recordings depict the demographic data of the traditional healers and the patients, the interaction process and the use of the traditional therapeutic techniques.

\section{Demographic data of traditional healers and the patients}

The traditional healers who participated in this research consisted of four (4) females and two (2) males, with the average age being thirty nine (39). In terms of age and gender, the distribution of patients who participated in the research was almost similar to that of traditional healers whom they consulted. Furthermore, the age of a traditional healer appeared to have no influence on the patient's choice to consult him/her. It also appeared that women seek the help of the traditional healer, more than men. The process of consultation consisted of two or more sessions and the consultations always took place at the traditional healers' premises. The initial contact made with the traditional healer appeared to be more out of the patient's own free will than in response to reference by friends or family.

\section{The interaction between the traditional healers and the patients}

The interaction between the traditional healer and the patient was based on a relationship consisting of a beginning, working and termination phase. On entering the consulting rooms, the patients showed respect for the traditional healers by entering in silence and removing their shoes at the door step. The traditional healer initiated the conversation by greeting the patient first in an atmosphere of tranquillity. Consultation was done with the patient sitting down on the floor facing the traditional healers. Those patients who sat on the chairs were beckoned by the traditional healers to do so.

Consultation was the beginning of the working phase, which was started by negotiating the fees to be paid prior to resuming divination. The fees varied depending on the problem of the patients. Money was used as means of payment and was agreed upon by both the traditional healers and the patients. The payment differed from one traditional healer to the other, with some requesting payment after the treatment is completed and the patient has been cured, or when the funds are available.

The process of divination involved a procedure which was performed to assess and diagnose the patient by using the divination tools, which differed from one traditional healer to the other. Some used "holy" bones and others used a lit candle and a glass of water. The consultation consisted of three phases, namely, the beginning phase, the working phase and the termination phase. During the beginning phase, rapport was built between the traditional healer and the patient and during this phase the traditional healer came to a meaningful diagnosis. The process of divination was an important part of the healing process and the traditional healer became active, while the patient was more passive and reacted only to the questions asked by the traditional healer. The period of divination varied amongst the traditional healers and depended on the patients' problems.

During divination all the traditional healers started with a prayer and made contact with the ancestors, even though the manner in which the prayer was said varied. They sprinkled snuff around the divination tools and spat saliva on the area where the "holy" bones were used. Objects in the form of a whisker, a spear or a stick were used to point at the divination tools as they interacted with the patients.

As part of the divination process, the problem was clarified. Patients had to agree to confirm the findings by saying "siya vuma". They seemed to understand the events that followed because they accepted the support and treatment offered by the traditional healer. After making the diagnosis, the traditional healer was seen to wrap the medicines, with the instructions written on the brown paper wrappers. If the medicine was wrapped in plastic, a separate piece of paper was wrapped inside with the medicines. It was also 
noted that certain medicines were immediately administered by the traditional healer, while others were given as treatment to take home. It was observed that all the patients were satisfied with the prescribed treatment, as well as with the answers which they received to their questions.

The interaction between the traditional healers and the patients ended in the termination phase. This phase included summaries of the conversations made during divination and when the treatment was prescribed. All the traditional healers invited the patients for a follow up visit but none referred the patients to other traditional healers or health care services.

It was observed that when the patients left the consulting rooms they did so in silence, put on their shoes at the doorstep and exchanged no greetings.

\section{The use of traditional therapeutic techniques}

The use of traditional therapeutic techniques was seen as an important aspect of the healing process. As the traditional healers worked from home, most of the treatment was used immediately after divination. The manner in which both the traditional healer and the patient used these techniques stems from the agreement into which they entered regarding the implementation process. The implementation process varied from one traditional healer to the other, according to their patients' problems. One could decide to start with oral administration while another may start with an enema.

The techniques that were used were mostly non invasive and consisted of natural herbs and plants. Much emphasis was placed on the way in which these medicines were to be used. The implementation process consisted of the following components:

- $\quad$ application of oily /fatty
medicines to the skin ,
pricking with a porcupine quill,
tapping with a horn of a goat or
ram,
- $\quad$ administration of oral medicines
constituted the major route,
- $\quad$ steamema,
- $\quad$ steam baths and bathing, and
eye, ear and nose instillation.

Home protection was done by means of spraying and burning incense inside and outside the house.

\section{The results of the semi- structured interviews}

The traditional healers' and the patients' views of the traditional healing process reflected three main categories, each with a number of sub-categories. The discussion below firstly focuses on the three main categories of the traditional healers' views regarding the healing process, therapeutic techniques carried out and the context of various relationships.

\section{The traditional healers' views about the traditional healing process}

The following discussion of the traditional healers' views are supported by quotations of the respondents and literature control.

\section{- Views regarding the healing process. Role expectations}

The traditional healers viewed themselves as having a role in healing people. All six traditional healers involved in this research, in principle supported the view that they heal people by giving them medicines suitable for their type of illness. The following quotations illustrates this:

"I heal ill people, I give them medicines that are suitable for their illness."

\section{"I offer people different types of treatment"}

Nzima, Edwards and Makunga, (1992:82 -93) confirms the results by stating that as a result of his/her ability to treat the patients, the traditional healer is known through out the land. Ngubane (1977:109), Gumede (1990:65) and Abdool Karim et al., (1994:5) agree that the traditional healers' ability to cure illnesses of supernatural origin is obtained from the use of herbs, rituals and ceremonies

The patients' self-
responsibility for healing
The traditional healer viewed the patient
as part of the healing process, and
expected the patient to take care of
herself. The following remarks confirm
these perceptions:

"I expect the patient to be responsible for her healing. The patient as part of healing is an honour to me, her role is largely determined by her illness and what she is able to do for herself."

"When I give them medicines to take home, I ask them to carry out the instructions as I tell them, we understand each other."

Mburu (In Singer, 1982:173) and Aakster (1989:298) support the findings and point out that carefully managed treatment and the satisfactory disclosure of information to the patient, as important aspects of healing.

Holdstock (1979:119) and Levitz (1992:2325) confirms these findings that the patients are given an opportunity to be partners in health care provision.

\section{Culture and belief system.}

The traditional healer and the patient shares the same worldview, as determined by culture, because they live in the same neighbourhood. The following remark is an example of this:

"Our understanding stems from the fact that I am the traditional healer. The patient has illness, she comes to me with the need to be cured. This makes us share the world which is controlled by culture."

Holdstock (1979:120) and Abdool Karim et al., (1994:2) confirm the research findings that the traditional healer shares with the patient a view of the world and the way in which it works. Arthur (1997:63) also concurs the findings that the traditional healer is seen as providing the solution for preventing and curing culturally perceived illnesses.

\section{- Therapeutic actions carried out}

- Therapeutic actions implemented by the traditional healer

The traditional healer used divination to understand the patient's problem and to determine the necessary treatment. The following quotation illustrate this:

"When a person is ill, then I start to get
deeper into his illness by first finding
out what the "holy" bones have to say."
Staugard (1985:81); Hammond Tooke
(1989:119)and Ingstad (1989:256) confirm
these findings by saying that the
therapeutic techniques, which the
traditional healer uses, are many and
includes divination, which is achieved 
by the use of "holy" bones. Abdool Karim et al., (1994:5) come to the same conclusion as the above authors when they find that divination is the first technique that the traditional healer uses, in order to communicate with the ancestors to find out what the patients' problem is prior to giving medications.

Various therapeutic actions used as part of healing

The traditional healers identified the following therapeutic actions as part of the healing process they use:

"I prefer to use bathing, enemata, steaming if it is necessary."

"When a person starts to come to me, I give her oral medicines to drink after boiling it."

Ngubane (1977:102); Gumede (1990:79) and Abdool Karim et al., (1994:5) made similar findings and indicate that medicines are prescribed and given by various routes. Edwards (1986:89) also concurs with this, in finding that medicines are administered by various routes, including methods such as boiling or burning.

\section{home}

Wrapping medicines for use at

This method is used to ensure the continued use of therapeutic techniques at home. Medicines are wrapped to be used at home according to instructions. The following two quotations are examples of what was said in this context:

"I am now going to give her prescriptions, medications that are for use at her home."

“I have each medicines' uses written out properly on a piece of paper, and this piece of paper is wrapped inside the plastic that I use to cover medicines with."

Literature does not make mention of the method that the traditional healer uses to give the medicines which are to be used at home, or whether they are wrapped up or placed in bottles. From the research findings, it appears that the traditional healer uses brown paper and plastic to wrap medicines for the patients to use at home, according to instructions which are written on a piece of paper that accompanies.

If a medicine is wrapped in plastic, a piece of paper with instructions is placed inside and wrapped with the medicine.

\section{Carrying out home visits}

The traditional healer visits very ill patients in their homes. In some cases where the traditional healer is unable to come to the patients' home, relatives or family members bring this patient to the traditional healers' home, or alternatively they come to fetch the traditional healer so that he treats the patient in his/her own home. These following responses were made in this regard:

"Yes, I do visit them when I have a
chance, and when that patient is very
ill, I do go over to see what is going on."

"Sometimes I am called to heal people at their homes, and these people come to fetch me, again this is where the family is involved in the healing process"

Literature is not specific about the traditional healer visiting patients voluntarily at their homes. However Ngubane (1977:103), Staugard (1985:123) and Abdool Karim et al., (1994:2) explains that the traditional healer relates best with the patient at home because of the relaxed and quiet atmosphere where individuality is maintained.

\section{The follow up process}

The patients were also expected to report back for review of their condition and to discuss the problem area if it was noticed that their conditions did not improve:

"I do ask them to return and tell me how they progress because I need to know if the patient feels better or not."

Levitz (1992: 36) supports these findings and argues that the ability to give answers about what is wrong in relation to problems of misfortune, is an important skill of the traditional healer. Gumede (1990:98) also agrees with this, by saying that the traditional healer treats the patient until he/she is satisfied with the treatment that has been given.

\section{Referral of patients}

If the traditional healer realises during the follow up process that the patient's problem has not been resolved, he/ she would request the patient to go to the clinic or surgery, or use other traditional healer's medicines. The following remarks are used as examples:

"When I start to realise that this patient is becoming worse, that is when I start to change from the treatment that I have been giving her."

"When still things do not work out according to plan then I request them to go to the hospital."

Watt and Van Warmelo (1960:47-63) and Ngubane (1981:361-367) made similar findings and indicate that when the traditional healer is faced with a disease he/she cannot handle, he/she requests the patient to seek other treatment or may change that treatment as the need arise. Green and Makhubu (1984:1071 - 1079) explains that although the traditional healer does not possess surgical skills, $\mathrm{he} / \mathrm{she}$ is able to assess the problems and therefore change treatment whenever necessary

\section{* The context of various relationships within the healing process. \\ Relationship with God and the ancestors}

This relationship stems from the fact that the traditional healer is given powers by the ancestors to deal with sick people. The following two quotations are examples of this:

"Traditional healing is a gift that you are given by God and the ancestors"

"It is healing given by our forefathers who have instructed us on the type of work that we are to treat people"

In the literature these findings are confirmed by Ngubane (1977:142), Gumede (1990:75) and Levitz (1992:23-26), who have found that the traditional healer view traditional healing as an effective form of healing and as a gift from God and the ancestors. The respondents also believed that they are guided and directed about what to do and where to look for the treatment.

- $\quad$ Relationship with the patient The relationship between the patient and traditional healer centres on the patient's illness and their mutual understanding to work together as far as the illness is concerned.

The following response from a participant confirm this:

"Our understanding stems from the fact that I am the traditional healer and the patient has an illness, she comes to me with a need to be cured." 
Mburu (in Singer, 1982: 172) and Abdool Karim et al., (1994:5) made similar findings, namely that the patient believe that his/her illness results from natural and supernatural causes, hence the need for the traditional healers' help in this situation.

\section{Relationship with the family}

In the view of the traditional healer, he/ she also has a clear relationship with the patient's family, in that the family must assist a patient who refuses to take medicines, must accompany the patient to the biomedical personnel and must report the progress of the patient to the traditional healer:

"I ask the relatives to send them to the doctors."

"I do request them to keep me informed about their progress."

Holdstock (1979:119), Freeman and Motsei (1992a: 1 186), Levitz (1992: 135) and Abdool Karim et al., (1994:2) come to the same conclusion about the importance of family involvement in the application of traditional therapeutic techniques, and points out that it plays an important role in maintaining social stability in the black society.

\section{- Relationship with the community}

The community views the traditional healer as a leader who helps with life and cures illness, and who is a happy, honoured and respectable person in the community. The following responses are used as examples:

"A leader that helps with life and cures illness."

"His healing you see it as the healing that helps."

Staugard (1985:112) as well as Freeman and Motsei (1992b:119) confirm the findings about the traditional healer' popularity in the communities because of his/her supernatural powers which are used to find the cause of the perceived disorder, and to correct or resolve it.

\section{The patients' views about traditional healing process}

The research found that the patients' perceptions of traditional healing, corresponds to that of the traditional healers. These views may be classified in the following main categories: the healing process; therapeutic actions carried out by the traditional healer; and the characteristics of the relationship between the patient and the traditional healer.

\section{* Healing process}

\section{- The traditional healers' ability}

\section{to treat cultural illness}

The patient viewed the traditional healer as able to treat black people's illnesses that are caused by transgressing cultural norms. These illnesses are viewed as culture bound, and this study has found that this aspect is not understood by biomedical personnel. These views are reflected in statements such as:

"One has to be treated by the traditional healer when having illness that is directed at traditional healing, illness like pollution where taboos are not respected."

Staugard (1986:99); Gumede (1990: 89) and Abdool Karim et al., (1994:2) concur with the findings about the belief of patients, and show that illness resulting from natural and supernatural causes are treated only by the traditional healer.

\section{The patient shares the} traditional healers' worldview

The patients' and the traditional healers' worldviews are similar, and are based upon the same premise of what constitutes illness/health. The experience of a shared worldview is enhanced by the fact that the traditional healer is also black, speaks the same language as the patient, lives in the same area and is accessible when needed.

"I say they know our customs, the way we black people live, it is their way of life, because they are black they have the ability to treat black people's illness"

Freeman and Motsei (1992a: 1186) and Abdool Karim et al., (1994:2) confirm the above argument that the traditional healer shares with the patients a view of the world and the way in which it works. Arthur (1997:67) supports this notion of a different worldview that is shared by the patient and the traditional healer, and refer to it as something completely alien to biomedical personnel.

\section{- Handling problems and difficulties}

Problems and difficulties are handled by paying a return visit to the traditional healer to get more information and clarity on the illness. The following remark is an example of this:

"I go back to the traditional healer to get more information and clarity."

Ngubane (1977:238) and Gumede (1992:5) affirms the findings that the patient returns to the traditional healer when there are no results or when he/she does not remember how the medicine must be used. Levitz (1992:16) also supports these results and explains that the patient returns to the traditional healer for a review of his /her progress when there are no evident results from the treatment which has been used.

\section{* Therapeutic actions carried out by the traditional healer. \\ - Different types of treatment used in traditional healing}

Patients view the therapeutic actions carried out by the traditional healer, in the same fashion as the traditional healers view them. The manner in which the divination is performed as well as the various routes of administering medicines are seen as methods used to solve or heal their culture bound illnesses or problems: "The traditional healer uses his 'holy' bones to see what is wrong with me and to tell me what I must do to be cured."

"The traditional healer treats me by giving me medicines to drink, others to vomit with and for enemas."

Ngubane (1977:106) refers to the use of divination before any treatment is commenced. Staugard (1985:9), Hammond-Tooke (1989:119) and Gumede (1990:116) all confirm these various routes of administering traditional medicines. These routes may vary according to the type of problem which is diagnosed during divination.

\section{- $\quad$ The problems and difficulties} encountered when using traditional medicines

When probiems and difficulties were encountered during the use of traditional medicines, the patient paid a return visit to the traditional healer to get more clarity on these problems. This situation is illustrated by the following responses of patients:

"I did forget how to use these herbs and I went back to ask for a re-explanation. "I go there myself to ask for clarity with these medicines."

Literature does not make mention of the 
instructions which the traditional healer gives to the patient. According to the information yielded by this research, however, it was identified as a reality, by the respondents, because they had to make a decision to return to the traditional healer to request for an explanation if there were misunderstandings about the use of medicines.

Uses of medicines at home.

Medicines for use at home should be used as prescribed, otherwise they would loose their effectiveness. Patients commented on this aspect in the following manner:

"The medicines that are used at home are for protecting the home and the children against evil. There are many types and he tells you how they work." "These that are used at home are used under strict instructions, if you do not use them in this way, they do not work."

Ngubane (1977:161) and Staugard (1985:65) come to a similar conclusion and mention that in the event where ancestral protection is withdrawn and problems of misfortune are experienced, it becomes necessary to perform rituals and ceremonies at home. Gumede (1990:88) also found that medicines may be at home for purposes of protecting the home as well as family.

\section{- Follow up process by the} traditional healer

During follow up by the traditional healer, the procedure of divination is repeated to further determine whether the problem could be solved and if it is necessary, to change the treatment.

Patients made remarks such as the following about this:

"Then he changes the medicines and gives me another one to use afresh and throws away the first one."

Ngubane (1977:102), Mburu (in Singer, 1982:177) and Abdool Karim et al., (1994:5) found that the traditional healer will identify the cause of the problem through supernatural divination, after which he will recommend a further course of action to the patient.

\section{The sources of medicines}

Medicines are obtained from the veld as roots of plants, barks from trees. Where medicinal herbs are not used, the traditional healer uses prayer, ash and "holy" water. One respondent gave the following account of this process:

"This healing is important to us because it is healing using herbs and plants." Watt and Van Warmelo (1960:53); Hammond-Tooke (1989:119) and Gumede (1990:112) indicate that $80 \%$ of medicines are of vegetable origin and that these medicines are picked from the "veld"; whereas Staugard (1985:107) and Freeman and Motsei (1992a:1186) make reference to prophets who use ash and water that have been prayed for.

\section{* The characteristics of the relationship between the patient and the traditional healer}

\section{- Interactive relationship}

The patient views the traditional healer as having an interactive relationship with him/her, based on the humane treatment by the healer, accessibility of the healer and the fact that healer listens to problems. This is illustrated by the following responses:

"This person, the traditional healer, he talks to us as human beings, not puppets or clowns."

"Yes, unlike you nurses who scolds and scolds when we do not remember or when we make mistakes, our people understands us better than you."

Staugard (1985: 123) and Levitz (1992:35) likewise refer to the phenomenon that the traditional healer has time to talk and listen to his/her patients. Freeman and Motsei (1992a:1186) and Musi (1996:31) also came to conclusion that biomedical personnel concentrate on the medical aspect of the disease and less on the patient as a human being.

\section{- The traditional healers' relationship with the ancestors}

In the patient's views the traditional healer's ability and powers to treat their culturally perceived illness is a gift bestowed upon him/her by God and the ancestors, and he/she has the ability to communicate with God and the ancestors, through the use of the "holy" bones:

"I prefer to go to him because he is able to communicate with the ancestors through the "holy" bones, therefore help me with the problems I have."

Ingstad (1989:251), Gumede (1990:90) and Abdool Karim et al., (1994:5) explain that the traditional healer communicates with the ancestors through offerings and mediates between the people, God and the ancestors. Levitz (1992:23) also supports the results and states that the ability to heal people is based on the answers the ancestors give during divination.

\section{Payment for the treatment}

It was noticed that the traditional healer did not expect immediate payment and that treatment was offered even when there was no payment. This is unlike the biomedical people who expect immediate payment for treatment and may even pursue patients for the payment. The following examples of the patients' responses illustrate this:

"Yes and more, he allow's me to be treated without money, my family can go to him even when I am not around, he looks after us all."

"The fact that when I also owe him he does not follow' me to ask for his monev; biomedical people, yes they sent you letters at home to remind you to come and pay:"

Green and Makhubu (1984: 1074), Ingstad (1989:256), Gumede (1990:90) and Musi (1996:31) also found that the treatment of one family member enables the traditional healer to have a relationship with the family where all the family members are treated even without immediate payment.

\section{Conclusions}

The demographic data of both the traditional healers and the patients, showed that both groups appeared to be younger than anticipated. This age factor did not affect the patients' decision to consult the traditional healer in times of need. The video recordings depicted the interaction between the traditional healer and the patient as a process involving divination (diagnosis) which was to be paid for in advance. During divination the traditional healers were seen to be emotional when "communicating with the ancestors." Once the problem was identified, the traditional healer and the patient agreed on the treatment to be used to resolve the problem. The treatment came in a form of various medicines, which were used immediately or were wrapped with the option to use at home. The patients posed no questions and accepted the medicines, with the instructions on how to used them. The traditional healers placed much emphasis on the manner in which the medicines should be used.

The conclusion regarding the traditional healer and the patients' views of traditional healing process was that the traditional healer's were endowed by the 
ancestors with the ability and power to treat the illnesses from which black people suffer because of transgressing cultural norms. Biomedical personnel were seen as unable to cure culture bound illnesses, and their services were only utilised as an alternative to traditional medicines when the latter did not to yield the expected results. The traditional healer and the patient both viewed the family as a support system in the healing process, and both felt that the patient was responsible for his/her own healing, because he/she was expected to carry out the instructions himself/herself when using the traditional therapeutic techniques.

\section{Recommendations}

Recommendations based on this research have implications for nursing practice, and are formulated as guidelines for the incorporation of traditional healers into the National Health Care Delivery System. These include the following:

- Facilitating changes in the perceptions and the attitudes of both the traditional healers and the biomedical personnel: develop mutual trust relationship, investigate views, needs and expectations of both traditional healers and biomedical personnel, and review attitudes of biomedical personnel towards the treatment of culturally perceived illnesses.

- Developing a committed relationship: organise workshops for information sharing avail training programmes for traditional healers introduce public education forums for both traditional healers and biomedical personnel, engender mutual respect and recognition, and teach biomedical personnel the fundamental principles of traditional healing

- Establish negotiations by means of which the National Health Care System acts as a facilitator

involve traditional healer as an active participant, review the needs and expectations of both groups, identify best ways of possible support and use of available resources,

facilitate reaching an agreement about applicable suitable methods of incorporation, accepting patients of the traditional healer,

and respecting the existence and services of each, and in principle agree about the definition of terms , cultural integration of illnesses in hospitals, ethical and legal implications of incorporation, reviewing of licensure or registration, and the training of traditional healers to detect diseases beyond their ability.

- $\quad$ Facilitate formation of a community based health care service:

avail services for culture bound illnesses,

provide traditional therapeutic techniques as part of package for each consultation, involve the family in health as well as the patient as a partner in health care provision, and refer patients to other traditional healers or to biomedical personnel if unable to handle the problem.

\section{BIBLIOGRAPHY}

AAKSTER, CW 1989: Assumptions governing approaches to diagnosis and treatment. Social Science Medicine. 29(3):293-300.

ABDOOL KARIM,SS; ZIQUGUPAGE, TT \& ARENDSE, R 1994: Bridging the gap - potential for a health care partnership between African traditional healers and biomedicine in South Africa. South African Medical Association Journal. December 1998: 1-16.

ANON. 1992: Traditional medicine deaths. Nursing RSA. 7(10):1-5.

ANON. 1996: Science versus tradition. True love. October 1996: 51 .

ARTHUR, ML 1997: The traditional biomedical Dichotomy in search of a common ground. Curationis. 20(2) July 1997:63-65.
AFRICAN NATIONAL CONGRESS. 1994: A national health plan for South Africa. Maseru : Bahr Mapping \& Printing.

BOTES, AC 1995: The operationalization of research model in qualitative methodology. RAUCUR. 1(1):1-9.

\section{DENOSA}

SEE

DEMOCRATIC NURSING

ORGANIZATION, 1997: Ethical standards for nurse researchers. Pretoria: DENOSA.

DORWICK, PW 1991: Practical guide to using video in the behavioural sciences. New York : John Wiley.

FITZPATRICK, JJ \& WHALL, AL 1996: Conceptual models of nursing: analyses and application. : Appleton Lange.

FREEMAN, M 1992: Negotiating the future of traditional healers in South Africa. Centre for Health Policy. Johannesburg: University of Witwatersrand.

FREEMAN, M \& MOTSEI, M 1992 (a): Planning health care in South Africa: Is there a role for traditional healers? Social Science Medicine. 34(1):1183-1190.

FREEMAN, M \& MOTSEI, M 1992 (b): Recognition and registration of traditional healers - possibilities and problems. Centre for Health Policy. Johannesburg: University of Witwatersrand.

GEORGE, BJ 1995: Nursing theories: The base for professional nursing practice. 4th ed. New Jersey: Prentice Hall.

GREEN, E \& MAKHUBU, L 1984: Traditional healers in Swaziland: Towards improved cooperation between traditional healers and modern health sectors. Social Science Medicine. 18(12): 1071-1074.

GUMEDE, MV 1990: Traditional healers: a medical doctor's perspective. Johannesburg: Vista University Press.

HAMMOND-TOOKE, D 1989: Rituals and medicines. Johannesburg: A.D. Donker.

HARAM, L 1991: Tswana medicine in Interaction with biomedicine. Social 


\begin{tabular}{|c|c|c|}
\hline CRITERIA & STRATEGY & APPLICATION \\
\hline $\begin{array}{l}\text { Credibility } \\
\text { Lincoln and Guba (in Krefting, 1991:214- } \\
\text { 217) }\end{array}$ & $\begin{array}{l}\text { Triangulation: by using two } \\
\text { investigators,two methods, and multiple } \\
\text { sources to confirm data }\end{array}$ & $\begin{array}{l}\text { Literature study was undertaken to } \\
\text { ground the interview schedules and } \\
\text { video recordings. } \\
\text { Field notes taken were made after video } \\
\text { recordings and the conducting of } \\
\text { interviews. } \\
\text { Cross validation was used during data } \\
\text { analysis by means of independent data } \\
\text { analysis and a consensus discussion } \\
\text { between the researcher and the co- } \\
\text { coder. } \\
\text { Extensive literature review was } \\
\text { undertaken. } \\
\text { Use of video recorder and semi- } \\
\text { stuctured interviews for data collection. } \\
\text { Field Notes were taken after video } \\
\text { recording and interviews. } \\
\text { Use of double coding during data } \\
\text { analysis. }\end{array}$ \\
\hline Applicability & $\begin{array}{l}\text { Application to other situations, contexts } \\
\text { and settings }\end{array}$ & $\begin{array}{l}\text { In this research, a dense description and } \\
\text { consistent reporting on the data that that } \\
\text { was collected were offered, in case other } \\
\text { researchers may want to criticise it or } \\
\text { conduct further studies. } \\
\text { The context was the three } \\
\text { aforementioned townships. }\end{array}$ \\
\hline Consistency & $\begin{array}{l}\text { The research must be replicated with the } \\
\text { same traditional healers and patients to } \\
\text { produce the same results } \\
\text { Auditability to increase reliability. }\end{array}$ & $\begin{array}{l}\text { The researcher gave a dense description } \\
\text { of data collection method, and of data } \\
\text { analysis. } \\
\text { A full description of the results and } \\
\text { discussion was presented. } \\
\text { The transcriptions and raw data are } \\
\text { available for auditing. }\end{array}$ \\
\hline Neutrality & $\begin{array}{l}\text { Clear connection between sources of data } \\
\text { and data description }\end{array}$ & $\begin{array}{l}\text { Neutrality was ensured by use of experts } \\
\text { in the auditing of the check list for the } \\
\text { video recording and for the format of } \\
\text { questions for the semi- structured } \\
\text { interviews. }\end{array}$ \\
\hline
\end{tabular}

Science Medicine. 33(2):167-175.

HOLDSTOCK, TL 1979: Indigenous healing in South Africa: a neglected potential. South African Journal of Psychology. 9: May 1979: 118-123.

HOPA, M; SIMBAYI, CC \& DU TOIT, CD 1998: Perceptions on integration of traditional and Western healing in the new South Africa. South African Journal of Psvchology. 28(1):8-14.

INGSTAD, B 1989: Healer, witch, prophet or modern health worker? The changing role of ngaka ya setswana (In WIDING, AJ \& VESTERLUND, A: Experience and pluralism: essays on African ideas of illness and healing. Stockholm: Almqvist \& Wikrell. PP 44-
75).

KREF TING, L 1991: Rigor in qualitative research; the assessment of trustworthiness. American Journal of Occupational Therapv. 45(3) March 1991:214-221.

LEVITZ, E 1992: Traditional medicine friend or foe? Publico. October 1992: 233- 
Further threats to validity (Woods and Catanzaro, 1988:137)
Observer effects: participants become aware that they are being observed.

Selection: threats embedded in possibility of sample not representing target population.

Regression due to data becoming old and loosing viability

Mortality: loss of participants
The tape recorder and video camera were placed to blend with the furniture and physical movements were minimised.

Selection of all participants was done by purposive voluntary sample according to the selection criteria.

Data was collected once only, by video taping same situations and asking same questions in the interviews.

Time between consenting to participate and collecting data was kept to within a month.

Data was collected in four to six weeks for this research.

Participants were motivated to turn up by availing food incentives.
236.

LINCOLN, YS \& GUBA, GE 1985:

Naturalistic inquiry. London: Sage.

MANKAZANA, EM 1979: A case for the traditional healer in South Africa. South African Medical Journal. 56: December 1979:1003-1007.

MANN, FA; WALKUP, RK; BERRYMAN, CR; PALMER, Q; BESSEY, MD; WILSON, AJ \& VANNIER, MW 1994: Computer base videotape analysis of trauma resuscitation for quality assurance and clinical research. The Journal of Trauma.36(2):226-230.

MBURU, FM 1977:The duality of traditional and Western medicine in Africa: mystics, myths and reality. Essays in critique of medical anthropology. Rochester: Oakland University.

MBURU, FM 1982: The duality of traditional and western medicine in Africa: mystics, myths and reality. (In SINGER, $P$ (Ed.) Traditional healing: new science or new colonialism. The Conch Sociological Journal of African Cultures and Literatures, 8(1\&2):158-185).

MOUTON, J \& MARAIS, DC 1996: Basic concepts in the methodology of social sciences. Pretoria: R.G.N. Publishers.

MUSI, O 1996: To allow Sangomas with patients. Citv Press. 24 Nov1996: 31.
NGUBANE, H 1977: Body and mind in Zulu medicine. London: Academic Press.

NGUBANE, H 1981: Aspects of clinical practice and traditional organisation of indigenous healers in South Africa. Social Science Medicine. 15B:361-365.

NZIMA, DR; EDWARDS, SD; MAKUNGA, NV 1992: Professionalization of traditional healers in South Africa: a case study. University of Zululand Journal of Psvchology. 8:82-91.

OMERY, A 1983: Phenomenology: a method for nursing research. Advances in Nursing Sciences. 5(2): January 1983: 49-63.

OSKOWITZ, B 1991: Bridging the communication gap between traditional healers and nurses. Nursing RSA. 6(7): July 1991:20-22.

SCHNETTLER, T; STOKER, DJ; DIXON, BJ; HERBST, D \& GELDENHUYS, E 1989: Survey methods and practice. Opinion Survey Centre: Pretoria Human Science Research Council.

SOUTH AFRICA (REPUBLIC), DEPARTMENT OF HEALTH 1996: Annual Report. Pretoria : Government Printers.

SOUTH AFRICA (Republic) 1997: White Paper for the transformation of the Health System in South Africa. (Notice 667). Govemment Gazette 17: 16 April 1997.
SOUTH AFRICA (REPUBLIC) DEPARTMENT OF HEALTH, 2000:

Guidelines for Good Practise in the Conduct of the Clinical Trials in Human participants in South Africa. Government Printers.

STAUGARD, F 1985: Traditional medicine in Botswana: traditional healers. Gaborone: Ipelegeng Publishers.

TESCH, 1990: Research design: qualitative and quantitative approaches. (In CRESSWELL, $\mathrm{J}$ (Ed.) A qualitative procedure. Library of congress catalogues in publication data. 133-157).

WATT, JM \& VAN WARMELO, NJ 1960: The medicine and practice of a Sotho doctor. Johannesburg: University of Witwatersrand.

\section{WHO SEE WORLD HEALTH ORGANIZATION.}

1978: The promotion and development of traditional medicine. Technical report series 622. Geneva: WHO Publications.

WOODS, NF \& CATANZARO, M 1988: Nursing research: Theory and practice. St Louis: C.V. Mosby.

YANGNI-ANGATE, A 1981: Understanding traditional medicine. World Health Forum. 2(3):240-244. 